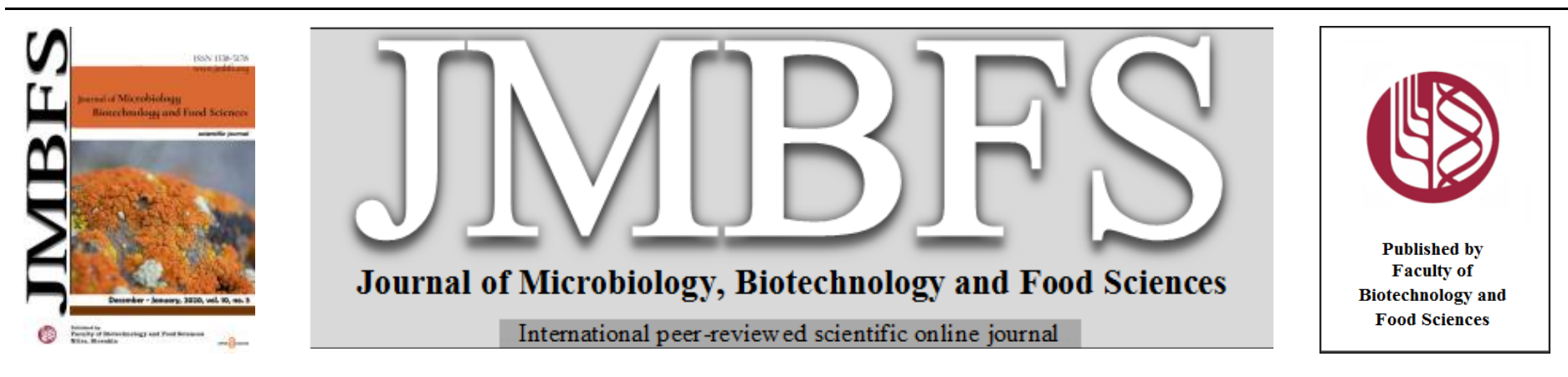

\title{
DEVELOPMENT OF FIBER AND MINERAL ENRICHED COOKIES BY UTILIZATION OF BANANA AND BANANA PEEL FLOUR
}

\author{
Md. Jahangir Alam*, Shamoli Akter, Shohana Afroze, Md. Tarikul Islam, Emdadul Haque Sayeem
}

Address(es):

Department of Food Technology and Nutritional Science, Faculty of Life Science, Mawlana Bhashani Science and Technology University, Santosh, Tangail- 1902, Bangladesh.

*Corresponding author: jahangirftns@gmail.com, jahangir@mbstu.ac.bd

doi: $10.15414 / j m b f s .2020 .10 .3 .329-334$

\section{ARTICLE INFO}

Received 7.3. 2019

Revised 17. 5. 2020

Accepted 30. 6. 2020

Published 1. 12. 2020

Regular article open $\partial_{\text {access }}$

\begin{abstract}
An experimental study was designed to formulate ready to eat cookies by incorporating banana and banana peel flour which is normally unused in Bangladesh but contains excellent amount of nutrients especially dietary fiber, essential vitamins and minerals. Cookies were prepared by replacing $5 \%$ (sample-1), $10 \%$ (sample-2) and 15\% (sample-3) of wheat flour with banana and banana peel flour. The proximate analysis and sensory parameters of those cookies were compared with control cookies where no banana and banana peel flour were added and designated as normal cookies ( $0 \%$ substitution). Functional properties were also evaluated and a significant difference found $(P<0.05)$ in $\mathrm{WHC}$, OHC, swelling capacity, emulsion activity, emulsion stability and flour dispersibility in banana peel flour when compared to wheat flour. On proximate analysis of cookies, significant variation $(P<0.05)$ was also observed in protein, ash, fiber and carbohydrate content of banana and banana peel flour cookies in a comparison to normal cookies. The increasing the substitution of banana and banana peel flour in cookies increased the ash and crude fiber content remarkably. About $15 \%$ substitution of banana and banana peel flour in cookies increased $93.25 \%$ crude ash (mineral) and $197.56 \%$ crude fiber than normal cookies. Energy values of the cookies were also evaluated and ranged between $480 \mathrm{Kcal}$ and $513 \mathrm{Kcal}$ per $100 \mathrm{~g}$, with sample- 3 cookies having the lowest value. In conclusion, the addition of both banana and banana peel flour in cookies by replacing $10 \%$ wheat flour were more acceptable with all quality characteristics.
\end{abstract}

Keywords: Banana, cookies, dietary fiber, functional properties, sensory evaluation

\section{INTRODUCTION}

Cookies are widely consumed as ready to eat and convenient foods throughout the world which gives more nutrient than any other single food sources (Raihan and Saini, 2017). Now-a-days, cookies represent the leading category of snack foods in the major parts of the world (Laura and Eric, 2014). Traditionally, cookies making processes are quite simple with some basic ingredients that consist of flour, sugar and eggs. Generally, soft wheat is used to make cookies (Laura, Eric and Emelem, 2013). Considering geographical scarceness, high cost and unavailibility of wheat flour, an alternative source of wheat flour are in high demand. Substation of wheat flour with other nutrient dense materials may reduce expense as well as import rate of wheat flour. This appeared the necessities of composite flour (Oyeku et al., 2008) which is defined as a mixture of whole wheat flour with non-wheat flours for the production of baking products such as biscuits, cookies, and pastas (Lakshmi, Swarnali and Usha, 2015). Nonwheat flour (substitute) should be available, accessible, economical and nutritionally enriched and able to fulfill the function of wheat flour (Akobundu, Ubbaonu and Ndupuh, 1998). It imparts an admirable means of increasing the nutrient content like protein, essential vitamins, important minerals, and bioactive compounds of foods by incorporation of readily available non wheat flour (Okafor, Ozumba and Solomon, 2002). This type of enrichment may play a significant role in developing countries like Bangladesh where malnutrition is prevalent. In this context banana and banana peel flour may be a great substitute of wheat flour because banana (Musa sapientum L) is one of the foremost fruit crops in Bangladesh in respect of production and area (BBS, 2006). It is also an economically considerable fruits in Bangladesh which is grown both in the homestead and commercial farms. Banana is one of the cheapest, delicious and most nourishing of all fruits. It is very much popular for its characteristics aroma, texture and easy to peel and eat. Banana contain most of the essential vitamins including vitamin-A, $\mathrm{C}$ and $\mathrm{B}_{6}$, important minerals, good source of fat free dietary fiber and a rich source of calories (Hossain, Abdulla and Majumder, 2016). Good sources of dietary fiber is very important for human health, in this concept interests are increasing to find out new sources of dietary fibers that add a wing to produce functional food to replace traditionally commercialized products. With these grounds, peels of different fruits, vegetables and herbs paying attention as they are rich source of natural dietary fiber and antioxidant. In this perspective, banana peel has attracted attention due to its rich source of dietary fiber (14.5\%). Besides, banana peels are normally unused in south Asia and also good sources of total starch $(73.4 \%)$, resistant starch $(17.5 \%)$, protein, fat and micronutrients (Juarez-Garcia et al., 2006). So that consumption of banana peels flour may play a significant role in human health (RodriguezAmbriz et al., 2008). New strategy in production of banana peel flour from unripe banana and incorporates it to different novel foods such as slowly digestible cookies (Aparicio-Saguilan et al., 2007) high-fiber and edible films (Rungsinee and Natcharee, 2007). Several researchers improve the nutritional quality of cookies by incorporating composite flour from different types of food sources (Chinma and Gernah, 2007; Singh, Riar and Saxena, 2008; Noor Aziah and Komathi, 2009). In this regard, this study was directed to assess the effects of substituting different amount of nutritionally enriched banana and banana peel flour with wheat flour into cookies and evaluate its effect on texture, sensory attributes and nutritional content.

\section{MATERIALS \& METHODS}

\section{Place of experiment}

The sample analyses were conducted in the laboratory of Food Technology and Nutritional Science (FTNS) Department, Mawlana Bhashani Science and Technology University (MBSTU), Santosh, Tangail-1902, Bangladesh.

\section{Collection of raw materials}

The banana (Musa sapientam L), which local name is "Sagor kola" was purchased from local market of Santosh, Tangail, Bangladesh. The other ingredients which were used in cookies production i.e. refined wheat flour, hydrogenated vegetable oil, sugar powder, vegetable oil (soybean), egg, whole 
milk, iodized salt, baking powder and required chemicals were used from the laboratory of FTNS department, MBSTU and some of them procured from the local market.

\section{Preparation of banana (unripe) peel flour}

At first the bananas were collected and washed with water to remove all harmful ingredients. After peeling, the peels were sliced and dipped for ten minutes in $0.5 \%(\mathrm{w} / \mathrm{v})$ citric acid solution to reduce enzymatic reaction. After drained out, the sliced were then dried in oven at $50^{\circ} \mathrm{C}$ for $16-20 \mathrm{hrs}$. The dried banana peels were then amalgamated by using a commercial blender and passes through 60 mesh screen to obtain fine banana peel flour. The dried banana peels powder were then stored in airtight packet at ambient temperature.

\section{Formulation of cookies}

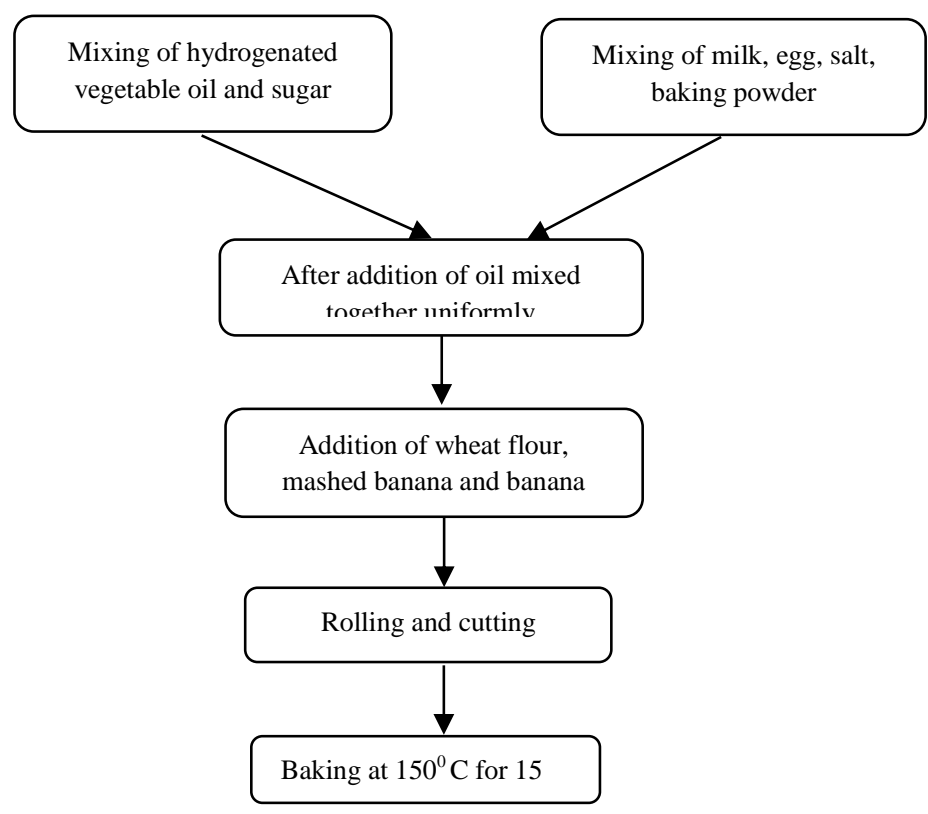

Figure 1 Flow chart of cookies preparation

Hydrogenated vegetable oil $(80 \mathrm{~g})$ and sugar $(200 \mathrm{~g})$ were uniformly mixed together for 3 minutes at a speed of 10 and $8 \mathrm{rpm}$ by rotary mixture machine. Then other ingredients such as milk, egg, salt and baking powder (composition shows in table-1) were mixed together at a speed of $6 \mathrm{rpm}$. After mixing above ingredients then added vegetable oil and uniformly mixed for 3 minutes at a speed of $8 \mathrm{rpm}$. Finally wheat flour, mashed banana and banana peel flour were added and uniformly mixed well together. The batter were rolled out and cut uniformly and send it to baking chamber and baked at $150^{\circ} \mathrm{C}$ temperatures for 15-16 minutes. When the color of cookies turned to light brown color it indicates the finished baked cookies. After baking, cookies were then cooled and packed in plastic packets. The ready to eat cookies were than stored at room temperature for further analysis.

Table 1 Formulation of cookies with banana and banana peel flour (for $1 \mathrm{~kg}$ )

\begin{tabular}{lcccc}
\hline Ingredients & $\begin{array}{c}\text { Normal } \\
\text { cookies }(0 \\
\%)\end{array}$ & $\begin{array}{c}\text { Sample 1 } \\
(5 \%)\end{array}$ & $\begin{array}{c}\text { Sample 2 } \\
(10 \%)\end{array}$ & $\begin{array}{c}\text { Sample 3 } \\
(15 \%)\end{array}$ \\
\hline Banana (g) & 0.00 & 25.00 & 50.00 & 75.00 \\
\hline $\begin{array}{l}\text { Banana peel flour } \\
(\mathrm{g})\end{array}$ & 0.00 & 25.00 & 50.00 & 75.00 \\
\hline Wheat flour $(\mathrm{g})$ & 500.00 & 450.00 & 400.00 & 350.00 \\
\hline Egg $(\mathrm{g})$ & 35.00 & 35.00 & 35.00 & 35.00 \\
\hline $\begin{array}{l}\text { Hydrogenated } \\
\text { vegetable oil }(\mathrm{g})\end{array}$ & 80.00 & 80.00 & 80.00 & 80.00 \\
\hline Whole milk & 80.00 & 80.00 & 80.00 & 80.00 \\
\hline Sugar $(\mathrm{g})$ & 200.00 & 200.00 & 200.00 & 200.00 \\
\hline Soybean Oil $(\mathrm{g})$ & 100.00 & 100.00 & 100.00 & 100.00 \\
\hline Salt $(\mathrm{g})$ & 2.5 .00 & 2.50 & 2.50 & 2.50 \\
\hline Baking powder $(\mathrm{g})$ & 2.5 .00 & 2.50 & 2.50 & 2.50 \\
\hline
\end{tabular}
sample were analyzed by using AOAC- 2000 method (AOAC, 2000). Energy value of the sample was calculated by using factor method described by by Chinma and Igyor and the Atwater factor method is [(9xfat $)+(4 x c a r b o h y d r a t e)+$ (4x protein)] (Chinma and Igyor, 2007)

\section{Physical characteristics of cookies}

Physical property of cookies is an important attributes which plays an important role to determine the consumer acceptability. AACC method was used to determine the diameter and thickness of the cookies (AACC, 2000). The Spread Factor (SF) of the cookies was determined according to the following formula: $\mathrm{SF}=($ Diameter/Thickness $\times$ Correction Factor $) \times 10$, where correction factor was 1.0 in this study at constant atmospheric pressure.

\section{Statistical analysis}

All the sample analyses were performed in triplicate and descriptive statistics were analyzed by using SPSS (Statistical Package for the Social Science) software package version 16.0 (SPSS Inc., Chicago, IL, USA) for all variables All of the values are expressed as the mean of three individual replicates \pm Standard Error Mean (SEM). All data were subjected statistically to ANOVA test (analysis of variance) and mean value were separated using Tukey's test (Steele Torrie, 1980). Differences between mean values were considered to be significant at $p<0.05$ 


\section{RESULTS AND DISCUSSION}

Chemical composition of raw material, different functional properties of banana peel flour and wheat flour, physical and nutritional properties of cookies were analyzed by using standard procedures. Determination of functional properties was important as it show the interaction among the composition, confirmation, structure, and physicochemical properties of protein and other food components (Kinsella, 1976). The effect of incorporation of different proportions of banana peel flour on nutritional and sensorial properties of cookies were also analyzed.

\section{Chemical composition of raw materials}

The raw materials, i.e., banana, banana peel flour and wheat flour were analyzed for chemical composition and the data are presented in table 2. Moisture content is one of the important indicators which influence shelf life, changes of flavor and enzyme activity and storage stability of flours. Research findings suggest that flours having more than $14 \%$ moisture content or 0.7 to $0.9 \mathrm{a}_{\mathrm{w}}$ are prone to mold growth and infestation by insects (Manley, 2000; Ayub, 2003). Banana pulp had the highest moisture content $(74.77 \%)$ whereas banana peel flour contained only $9.40 \%$ moisture and wheat flour had $10.90 \%$ moisture. These results are quite similar to the results found in sweet potato flour by Singh et al., (2008). Moisture content in flour is mainly affected by amount of moisture used for wheat conditioning and also for type of wheat milling. Another functional component of flour is percentage of protein content by which flour specification, flour condition and quality of the product depends. Protein content varies from 6-20\% in different varieties of wheat (Kent, 1983). The percentage of protein of the banana and banana peel flour was found quite low when compared with wheat flour. These values are quite lower than those found in wheat flour $13.20 \%$ by Raihan and Saini (2017) and $13.60 \%$ by Juma et al., (2018). Fat percentage was found highest in banana peel flour $(4.47 \%)$ on the other hand the lowest content found in the banana. Banana peel flour had a significantly higher amount of ash content $(7.66 \%)$ than banana $(1.27 \%)$ and wheat flour $(0.44 \%)$. Percentage of ash content in banana peel flour is relatively higher than those reported in mung bean flour $3.42 \%$ by Kavitha \& Parimalavalli (2014) and 2.6-3.5\% in banana flour (Da Mota et al., 2000). The high crude ash content of banana peel flour can be attributed to relatively high mineral content. Banana peel flour is rich in iron, zinc, calcium, magnesium, phosphorus, and potassium (Michel et al., 2016) Similarly, banana is rich in potassium (Bezemek, 2015). The crude fiber content was also significantly high in banana peel flour $(8.82 \%)$ than banana $(1.34 \%)$ and wheat flour $(0.34 \%)$. The high fibers content in banana peel flour $(11.81 \mathrm{~g} / 100 \mathrm{~g}$ dry peel) also observed by Romelle et al., (2016). Banana peels contain both soluble and insoluble dietary fiber. Happi Emaga et al., (2007) found insoluble dietary fiber; cellulose 7 to $12 \mathrm{~g} / 100 \mathrm{~g}$, lignin 6.4 to $9.6 \mathrm{~g} / 100 \mathrm{~g}$ and hemicelluloses 6.4 to $8.4 \mathrm{~g} / 100 \mathrm{~g}$, in banana peels and also found soluble dietary fiber that is pectin 13.0 to $21.7 \mathrm{~g} / 100 \mathrm{~g}$. High fiber diet are very important for adult, in that, it promotes the wave-like contraction that helps to move food through the intestine and also easing the passage of waste and expanding the inside walls of the colon to make an anti-constipation effect (Eromosele and Eromosele, 1993). Crude fibers are known to aid digestion, absorb water and make stools larger and softer so as prevent constipation (Ayoola and Adeyeye, 2009). The high level of fiber in the plantain suggests that it is capable of promoting digestion as fibers are known to aid and speed up the excretion of wastes and toxins from the body, and also prevent colon cancer as it prevents waste or toxins to stay in the intestine for too long (Ogbonna et al., 2016). As carbohydrate content of flours calculated by difference method, it varied from 19.09 to $77.94 \%$.

Table 2 Chemical composition of raw materials

\begin{tabular}{lcccccc}
\hline Sample & Moisture $(\%)$ & Ash $(\%)$ & Protein $(\%)$ & Fat $(\%)$ & Fiber $(\%)$ & Carbohydrate $(\%)$ \\
\hline Banana & $74.77 \pm 1.12$ & $1.27 \pm 0.56$ & $3.25 \pm 0.16$ & $0.28 \pm 0.06$ & $1.34 \pm 0.09$ & $19.09 \pm 2.47$ \\
\hline Banana peel flour & $9.40 \pm 2.26$ & $7.66 \pm 0.84$ & $2.73 \pm 0.10$ & $4.47 \pm 0.17$ & $8.82 \pm 0.17$ & $66.92 \pm 3.56$ \\
\hline Wheat flour & $10.90 \pm 2.43$ & $0.44 \pm 0.12$ & $8.96 \pm 0.18$ & $1.42 \pm 0.15$ & $0.34 \pm 0.16$ & $77.94 \pm 4.12$ \\
\hline Data are expressed as Mean \pm Standard Error Mean of three replicate measurements &
\end{tabular}

\section{Functional properties of wheat and banana peel flour}

Test of functional properties is very important because it describes how ingredients behave during preparation and cooking. It also describes how they affect the quality of finished food product in terms of looks, tastes, and feels WHC, OHC, SC, EA, ES and FD are important properties of flour both of physicochemical and technological point of views. WHC is the amount of water that can be bound in fiber until the application of external force. In this study, a significant $(P<0.05)$ difference was found in WHC of banana peel flour and wheat flour. Mean WHC of banana peel flour found slightly higher $(4.58 \mathrm{~g} / \mathrm{g}$ dry sample) than WHC of wheat flour (3.19 g/g dry sample) (Table-3). These findings are quite low compared to dietary fiber found by Larrauri et al., (1996) in mango (12 to $15 \mathrm{~g}$ water/g dry sample) and mango peel (11 to $12 \mathrm{~g}$ water/g dry sample). Whereas, the mean $\mathrm{OHC}$ of wheat flour was found slightly higher that was $0.63 \mathrm{~g} / \mathrm{g}$ dry sample than $\mathrm{OHC}$ of banana peel flour that was $0.44 \mathrm{~g} / \mathrm{g}$ dry sample which was also statistically significant $(P<0.05)$. These findings are quite similar to the results observed by Kaushal et al., (2012). Another functional property of flour is swelling capacity and it depends on variety, size of particles and types of processing methods. A significant $(P<0.05)$ difference was found in swelling capacity of wheat flour and banana peel flour. Swelling capacity of wheat flour and banana peel flour found $15 \mathrm{ml}$ and $13.50 \mathrm{ml}$ respectively. Emulsion Activity and Emulsion Stability both were found higher in wheat flour $(41.20 \%$ and $35.10 \%)$ than banana peel flour $(36 \%$ and $30.50 \%)$ respectively which was statistically significant $(P<0.05)$. A significant $(P<0.05)$ variation was found in flour dispersibility test of banana peel flour and wheat flour. About $61 \%$ flour dispersibility found in banana peel flour whereas $66.56 \%$ found in whole wheat flour.

Table 3 Functional properties of wheat flour and banana peel flour

\begin{tabular}{lccc}
\hline Properties & Wheat flour & Banana peel flour & P value \\
\hline Water holding capacity (g water/g dry sample) & $3.19 \pm 0.12$ & $4.58 \pm 0.08$ & 0.000 \\
\hline Oil holding capacity (g oil/g dry sample) & $0.63 \pm 0.14$ & $0.44 \pm 0.22$ & 0.004 \\
\hline Swelling capacity (ml) & $15.00 \pm 0.92$ & $13.50 \pm 0.85$ & 0.001 \\
\hline Emulsion Activity (\%) & $41.20 \pm 3.42$ & $36.00 \pm 2.64$ & 0.000 \\
\hline Emulsion Stability (\%) & $35.10 \pm 2.12$ & $30.50 \pm 3.84$ & 0.000 \\
\hline Flour Dispersibility (\%) & $66.56 \pm 1.28$ & $61.00 \pm 3.20$ & 0.000 \\
\hline $\begin{array}{l}\text { Data are expressed as Mean } \pm \text { Standard Error Mean of three replicate measurements. Statistically significant } p<0.05 \text { when compared } \\
\text { wheat flour to banana peel flour. }\end{array}$ & &
\end{tabular}

\section{Nutritional values of the cookies}

According to Table 4, with increasing the substitution of banana and banana peel flour, the moisture content was increased in cookies. Moisture content ranged from $2.28 \%$ to $3.35 \%$ and highest moisture content were observed in $10 \%$ banana and banana peel flour cookies. Moisture content increased with the incorporation of banana and banana peel flour which was statistically significant $(P<0.05)$. The water binding capacity of banana peel flour found quite higher than the water binding capacity of wheat flour. These findings are quite similar to the study of Bertagnolli et al. (2014), who found that cookies made from composite flour that contain guava peel flour has moisture ranged from 2.7 and $4.9 \%$. Maximum variation in moisture content was found 2.47 to $8.75 \%$ in commercially available biscuits whether fat content varies between 1.04 to $14.82 \%$ (Semwat et al.,
1996). The substitution of banana and banana peel flour to refined wheat flour at levels of 5-15\% showed a lowering effect on the protein contents of the cookies (Table 4). A statistically significant variation $(P<0.05)$ was also found in protein content of all sample cookies. Possible reason for this may be higher percentage of protein in wheat flour than banana and banana peel flour. This finding is quite lower than the cookies made with $100 \%$ pigeon pea flour (12.97\% protein) reported by Okpala and Okoli (2011). The protein content found in banana and banana peel flour cookies was close agreement to the cookies of taro-wheat blend (Ojinnaka. 2009). There was no major distinction found in the fat percentage of the cookies made by substitution of 5 to $15 \%$ banana and banana peel flour. There was no significant variation $(P>0.05)$ found in cookies except sample-2 and sample- 3 cookies 
Table 4 Nutritional values of the cookies

\begin{tabular}{lcccc}
\hline Nutrients & Normal cookies $(0 \%)$ & Sample 1 $(5 \%)$ & Sample 2(10\%) & Sample 3 (15\%) \\
\hline Moisture (\%) & $2.28 \pm 0.12^{\mathrm{a}}$ & $2.87 \pm 0.02^{\mathrm{b}}$ & $3.35 \pm 0.14^{\mathrm{c}}$ & $3.02 \pm 0.11^{\mathrm{d}}$ \\
\hline Protein (\%) & $10.19 \pm 1.08^{\mathrm{a}}$ & $8.53 \pm 1.03^{\mathrm{b}}$ & $7.20 \pm 1.24^{\mathrm{c}}$ & $6.94 \pm 0.20^{\mathrm{d}}$ \\
\hline Fat $(\%)$ & $25.96 \pm 1.34^{\mathrm{a}}$ & $25.80 \pm 0.46^{\mathrm{a}}$ & $27.16 \pm 0.86^{\mathrm{a}}$ & $21.96 \pm 0.67^{\mathrm{b}}$ \\
\hline Ash (\%) & $1.63 \pm 0.04^{\mathrm{a}}$ & $2.42 \pm 0.08^{\mathrm{b}}$ & $2.72 \pm 0.02^{\mathrm{c}}$ & $3.15 \pm 0.53^{\mathrm{d}}$ \\
\hline Crude fiber $(\%)$ & $0.41 \pm 0.02^{\mathrm{a}}$ & $0.65 \pm 0.03^{\mathrm{b}}$ & $0.91 \pm 0.04^{\mathrm{b}}$ & $1.22 \pm 0.10^{\mathrm{b}}$ \\
\hline Carbohydrate $(\%)$ & $59.53 \pm 2.06^{\mathrm{a}}$ & $59.73 \pm 0.86^{\mathrm{b}}$ & $58.66 \pm 0.92^{\mathrm{c}}$ & $63.71 \pm 1.42^{\mathrm{d}}$ \\
\hline Energy (kcal/100g) & $513^{\mathrm{a}}$ & $505^{\mathrm{b}}$ & $508^{\mathrm{c}}$ & $480^{\mathrm{d}}$
\end{tabular}

Data are expressed as Mean \pm Standard Error Mean of three replicate measurements. Values in the same row with different superscripts are statistically significant from each other $(p<0.05)$. Normal cookies $=100 \%$ wheat flour, Sample-1=Wheat flour substituted with $5 \%(2.5 \%)$ banana $+(2.5 \%)$ banana peel flour, Sample-2=Wheat flour substituted with $10 \%(5 \%)$ banana $+(5 \%)$ banana peel flour, Sample-3=Wheat flour substituted with $15 \%(2.5 \%)$ banana $+(2.5 \%)$ banana peel flour.

A noteworthy difference $(P<0.05)$ was found in ash content of all sample cookies and it increased from 1.63 to $3.15 \%$. The maximum ash content $(3.15 \%)$ was found in $15 \%$ banana and banana peel flour cookies followed by $10 \%(2.72 \%)$, while the lowest value in normal cookies $(1.63 \%)$. Increasing trend of ash content in cookies with increasing substitution of banana and banana peel flour may be relate to higher ash content in the banana peel flour than wheat flour. Similar Increasing pattern in ash content with increasing pitaya peel flour substitution in cookies also observed by Bala et al., (2015) and increasing nature related with the higher ash content in the pitaya peel flour $(10.57 \%)$ than refined flour $(0.98 \%)$. The fiber content of the cookies has increased with increased the substitution of banana and banana peel flour but significant differences $(\mathrm{P}<0.05)$ found between normal and samples-1 cookies. The highest amount of dietary fiber was found in $15 \%$ banana and banana peel flour cookies on the other hand, the lowest amount found in cookies made by without addition of banana and banana peel flour. These findings are quite similar to the results obtained by Nassar et al., (2008) who also found increasing pattern of fiber with increasing substation of citrus by-products flour with wheat flour. Increasing trend of crude fiber content also observed by Inyang and Wayo (2005) in their sesame fortified cookies from 0.46 to $1.09 \%$. This study fulfilled the recommended range of FAO and WHO (1994), as they suggested not to add more than $5 \mathrm{~g}$ dietary fiber per $100 \mathrm{~g}$ dry matter.

$\underline{\text { Table } 5 \text { Crude fiber and ash improving effect of banana and banana peel flour }}$

\begin{tabular}{lcccc}
\hline Nutrient & Normal cookies (0\%) & Sample-3 $(15 \%)$ & $\begin{array}{c}\text { Difference } \\
\text { (Sample-3- Normal cookies) }\end{array}$ & Increased amount \\
\hline Crude Ash (\%) & 1.63 & 3.15 & 1.52 & $93.25 \%$ \\
\hline Crude fiber (\%) & 0.41 & 1.22 & 0.81 & $197.56 \%$ \\
\hline
\end{tabular}

Carbohydrate content of prepared cookies was calculated by difference method and there was no remarkable variation found in carbohydrate content of cookies Carbohydrate content found highest in $15 \%$ banana and banana peel flour cookies followed by $5 \%$ banana and banana peel flour cookies. These results are in close relation with the cookies made from cocoyam-wheat blends (Ojinnaka, Akobundu and Iwe, 2009). The energy values of the prepared cookies ranged from 480 to $513 \mathrm{Kcal} / 100 \mathrm{~g}$. The slight variation on energy value due to the variation of protein and fat content of cookies outweighs the decrease in carbohydrate content.

\section{Physical characteristics of cookies}

The cookies were also analyzed for their physical properties such as thickness, diameter and spread factor shown in table 6. A significant variation $(\mathrm{P}<0.05)$ observed in diameter and thickness of the cookies. The cookies diameter ranged from $5.75 \mathrm{~cm}$ to $5.86 \mathrm{~cm}$. while thickness of the cookies ranged from $1.22 \mathrm{~cm}$ to 1.42 centimeter. The highest thickness was found in cookies made by without addition of banana and banana peel flour. As spread factor was calculated from diameter and thickness of the cookies there was a significant variation $(\mathrm{P}<0.05)$ found in spread factor. The highest spread factor was found in $10 \%$ banana and banana peel flour cookies and lowest one found in normal cookies. A similar inclination in cookies observed by Chinma and Gernah (2007) made from mango, cassava and soybean composite flour. Higher spread ratios in cookies having are considered the most desirable (Kirssel and Prentice, 1979)

Table 6 Physical characteristics of cookies

\begin{tabular}{lcccc}
\hline Physical properties & Normal cookies $(0 \%)$ & Sample 1 (5\%) & Sample 2 (10\%) & Sample 3 (15\%) \\
\hline Diameter $(\mathrm{cm})$ & $5.82 \pm 0.12^{\mathrm{a}}$ & $5.76 \pm 0.03^{\mathrm{b}}$ & $5.86 \pm 0.22^{\mathrm{c}}$ & $5.75 \pm 0.11^{\mathrm{d}}$ \\
\hline Thickness $(\mathrm{cm})$ & $1.42 \pm 0.24^{\mathrm{a}}$ & $1.30 \pm 0.17^{\mathrm{b}}$ & $1.22 \pm 0.32^{\mathrm{c}}$ & $1.28 \pm 0.28^{\mathrm{d}}$ \\
\hline Spread Factor & $40.99 \pm 1.18^{\mathrm{a}}$ & $44.31 \pm 0.68^{\mathrm{b}}$ & $48.03 \pm 2.52^{\mathrm{c}}$ & $44.92 \pm 1.85^{\mathrm{d}}$ \\
\hline $\begin{array}{l}\text { Data are expressed as Mean } \pm \text { Standard Error Mean of three replicate measurements. Values in the same row with different superscripts are } \\
\text { statistically significant from each other }(p<0.05) \text {. Normal cookies=100\% wheat flour, Sample-1=Wheat flour substituted with 5\% (2.5\%) } \\
\text { banana + (2.5\%) banana peel flour, Sample-2=Wheat flour substituted with 10\% (5\%) banana + (5\%) banana peel flour, Sample-3=Wheat } \\
\text { flour substituted with 15\% (2.5\%) banana + (2.5\%) banana peel flour. }\end{array}$
\end{tabular}

\section{Sensory evaluation of functional cookies}

Sensory evaluation of the cookies depends on its appearance, color, flavor and aroma, texture and overall acceptability taste of the sample. All the panelists were having excellent capability (trained on sensory evaluation) to evaluate the sensory evaluation of banana and banana peel flour cookies.

\section{Color and appearance acceptability}

Table 7 shows the sensory evaluation score of functional cookies supplemented with different level of banana and banana peel flour. Besides normal cookies, sample-2 cookies liked very much by the panelist (score 7.5). On the other hand, $15 \%$ substitution of banana and banana peel four got the lowest score on color and appearance. A statistical significant variation $(\mathrm{P}<0.05)$ found on color and appearance score. Increasing the supplementation of banana peel flours with wheat flour increased the darkness of cookies may be the prime reason for find objectionable of the cookies.

\section{Texture and consistency acceptability}

Texture and Consistency depends upon mainly the rate of development of the dough and the proportion of sugar used. Table 7 shows that the normal cookies and sample-1 got the highest score on Texture and Consistency of cookies (score 7) and sample-2 got the second highest score on Texture and Consistency. The softness of the texture of normal, sample-1 and sample-2 cookies may be the main reason for getting the highest score by the panelist. Similarly the hardness of sample-4 than normal cookies may be the reason for getting lowest score. The result revealed that, increasing the substitution of banana and banana peel flour increases the hardness of cookies. 


\section{Taste acceptability}

Taste is also influenced by the quality of the raw materials used in the processing unit of cookies. No significant variation $(\mathrm{P}>0.05)$ found in taste acceptability taste. About $15 \%$ substitution of banana and banana peel flour cookies got the lowest score on taste acceptability taste.

Table 7 Comparison of the different organoleptic quality parameters of functional cookies

\begin{tabular}{lcccc}
\hline Sensory Evaluation & Normal cookies $(0 \%)$ & Sample 1 (5\%) & Sample 2 (10\%) & Sample 3 (15\%) \\
\hline Color and Appearance & $7.5 \pm 0.12^{\mathrm{a}}$ & $6.1 \pm 0.22^{\mathrm{b}}$ & $7.5 \pm 0.08^{\mathrm{c}}$ & $5.6 \pm 0.22^{\mathrm{d}}$ \\
\hline Texture and Consistency & $7.0 \pm 0.07^{\mathrm{a}}$ & $7.0 \pm 0.19^{\mathrm{a}}$ & $6.5 \pm 0.23^{\mathrm{a}}$ & $5.4 \pm 0.11^{\mathrm{a}}$ \\
\hline Taste & $7.5 \pm 0.08^{\mathrm{a}}$ & $7.0 \pm 0.09^{\mathrm{a}}$ & $7.0 \pm 0.13^{\mathrm{a}}$ & $6.3 \pm 0.80^{\mathrm{a}}$ \\
\hline Aroma & $7.0 \pm 0.16^{\mathrm{a}}$ & $7.0 \pm 0.24^{\mathrm{b}}$ & $6.0 \pm 0.07^{\mathrm{c}}$ & $5.8 \pm 0.33^{\mathrm{d}}$ \\
\hline Overall Acceptability & $6.5 \pm 0.28^{\mathrm{a}}$ & $6.5 \pm 0.36^{\mathrm{b}}$ & $7.5 \pm 0.16^{\mathrm{c}}$ & $5.3 \pm 0.08^{\mathrm{d}}$ \\
\hline
\end{tabular}

Data are expressed as Mean \pm Standard Error Mean $(\mathrm{n}=15)$. Values in the same row with different superscripts are statistically significant from each other $(p<0.05)$. Normal cookies $=100 \%$ wheat flour, Sample-1=Wheat flour substituted with $5 \%(2.5 \%)$ banana $+(2.5 \%)$ banana peel flour, Sample$2=$ Wheat flour substituted with $10 \%(5 \%)$ banana $+(5 \%)$ banana peel flour, Sample-3=Wheat flour substituted with $15 \%(2.5 \%)$ banana $+(2.5 \%)$ banana peel flour.

\section{Aroma acceptability}

The aroma of the products depends on the volatile constituents of raw materials. Normal Cookies and sample-1 showed the best aroma acceptability taste score comparable to other functional cookies. On the other hand, sample-4 neither like nor dislike on flavor by the panelist. The score on aroma acceptability taste was statistically significant $(\mathrm{P}<0.05)$

\section{Overall acceptability}

Hedonic scale showed that the $10 \%$ substitution of banana and banana peel flour got the highest score on overall acceptability taste. The score on overall acceptability taste was highly significant $(\mathrm{P}<0.05)$

\section{CONCLUSION}

The outcome of the present study reveals that, higher the substitution of banana and banana peel flour with wheat flour increased the percentage of crude ash and crude fiber content in cookies. There was a significant variation found in protein, fat, carbohydrate and energy content of prepared cookies. In sensory evaluation test, $10 \%$ substitution of banana and banana peel flour cookies were more acceptable with all quality characteristics by the panel member. So substitution of banana and banana peel flour with wheat flour may be more nutritious and cost effective.

\section{DECLARATIONS}

Conflict of Interest: Authors have declared that no competing interests exist.

Authors' contributions: The authors contributed equally to the concept, experiment, analysis of data and writing of manuscript. All authors read and approved the final manuscript.

Funding: The authors provided personal resources for funding this paper.

Acknowledgements: The authors would like to offer special gratitude and thanks to Department of Food Technology and Nutritional Science, Mawlana Bhashani Science and Technology University, Santosh, Tangail-1902 for the laboratory facilities provided during the present study.

\section{REFFERENCES}

A. O. A. C. (2000). Official methods of food analysis, $15^{\text {th }}$ edn. Association of official Analytical Chemists, Washington, D.C.

A. A. C. C. (2000). Approved Methods of American Association of Cereal Chemists, 10th Ed., American Association of Cereal Chemists, St. Paul.

Akobundu, E. N. T., Ubbaonu, C. N. and Ndupuh, C. E. (1998). Studies on the baking potential of non-wheat composite flours. J Food Sci Technol, 25, 211 214. https://doi:10.1016/j.jfca.2006.07.005

Aparicio-Saguilan, A., Sayago-Ayerdi, S. G., Vargas-Torres, A., Juscelino, T. Ascencio-Otero, T. E., \& Bello-Perez, L. A. (2007). Slowly digestible cookies prepared from resistant starch-rich lintnerized banana starch. Journal of Food $\begin{array}{llll}\text { Composition andysis, 20(3-4), 175-181. } & \end{array}$ https://doi.org/10.1016/j.jfca.2006.07.005

Ayoola, P. B and Adeyeye, A. (2009). Proximate Analysis and Nutrient Evaluation of Some Nigerian Pawpaw Seeds Varieties, Science Focus, 14(4), 554-558.

Ayub, M., Wahab, S. and Durrani, Y. (2003). Effect of Water Activity (Aw) Moisture Content and Total Microbial Count on the Overall Quality of Bread. International Journal of Agriculture \& Biology, 5(3), 274-278.
Bala, A., Gul, K. and Riar, C. S. (2015). Functional and sensory properties of cookies prepared from wheat flour supplemented with cassava and water chestnut flours. Cogent Food and Agriculture, 1(1), 1019815 https://doi.org/10.1080/23311932.2015.1019815

B. B. S. (2006). Year Book of Agricultural Statistics of Bangladesh. Bangladesh Bureau of Statistics, Planning Division. Ministry of Planning Government of the people's Republic of Bangladesh, 86p

Bertagnolli, S. M. M., Silveira, M. L. R., Fogaça, A. D. O., Umann, L., \& Penna, N. G. (2014). Bioactive compounds and acceptance of cookies made with Guava peel flour. Journal of food science Technology, 34(2), 303-308 http://dx.doi.org/10.1590/fst.2014.0046

Bezemek, M. W. (2015). Bananas: rich in fiber, vitamins, and minerals. Retrieved from http://ceimperial.ucanr.edu/files/218815.pdf on 28 Mar 2017.

Chinma, C. E. and Gernah, D. I. (2007). Physichochemical and sensory properties produced of cookies produced from cassava/ soybean/mango composite flours. Journal of Food Technology, 5(3), 256-260.

Chinma, C. E. and Igyor, M. A. (2007). Micronutrients and anti-nutritional contents of selected tropical vegetable grown in South East, Nigeria. Nig.Food Journal, 25(1), 111-116. http://dx.doi.org/10.4314/nifoj.v25i1.33659

Da Mota, R.V., Lajolo, F. M., Ciacco, C. \& Cordenunsi, B. R. (2000) Composition and functional properties of banana flour from different varieties. Starch-Stärke, 52(3), 63-68. https://doi.org/10.1002/(SICI)1521 379X(200004)52:2/3<63::AID-STAR63>3.0. CO;2-V

Eromosele, I. C and Eromosele, C. O. (1993). Studies on chemical composition and physicochemical properties of seeds of some wild plant (Netherland). Plant Food for Human Nutrition, 43(3), 251-256. https://doi.org/10.1007/bf01886227

FAO/WHO. (1994). Codex Alimentarius: foods for special dietary uses (including foods for infants and children). $2^{\text {nd }}$ edn. FAO, Rome.

Happi Emaga, T., Andrianaivo, R. H., Wathelet, B., Tchango, J. T. and Paquot, M. (2007). Effects of the stage of maturation and varieties on the chemica composition of banana and plantain peels. Food Chemistry, 103(2), 590-600 https://doi.org/10.1016/j.foodchem.2006.09.006

Hossain, M. M., Abdulla, F. \& Majumder, A. K. (2016). Forecasting of Banana Production in Bangladesh. American Journal of Agricultural and Biological Sciences, 11 (2), 93-99. http://doi:10.3844/ajabssp.2016.93.99

Inyang, U. E. and Wayo, A. U. (2005). Fortification of cookies with dehulled sesame seed meal. Journal of Tropical Science, 45(3), $103-105$ https://doi.org/10.1002/ts.2

Juarez-Garcia, E., Agama-Acevedo, E., Sayago-Ayerdi, S. G., RodriguezAmbriz, S. L. \& Bello-Perez, L. A. (2006). Composition, digestibility and application in bread making of banana flour. Plant Foods for Human Nutrition, 61(3), 131-137. http://doi:10.1007/s11130-006-0020-x

Juma, N. A. Alviola and Viena, G. Monterde. (2018). Physicochemical and Functional Properties of Wheat (Triticum aestivum) and Selected Local Floursin the Philippines. Philippine Journal of Science, 147 (3), 419-430.

Kaushal, P., Kumar, V. \& Sharma, H. K. (2012). Comparative study of physicochemical, functional, anti-nutritional and pasting properties of taro (Colocasia esculenta), rice (Oryza sativa), pegion pea (Cajanus cajan) flour and their blends. LWT-Food Sci Technol, 48(1), 59-68. https://doi.org/10.1016/j.lwt.2012.02.028

Kavitha, S., Parimalavalli, R. (2014). Effect of processing methods on proximate composition of cereal and legume flours. J Hum. Nutr. Food Sci, 2, 1051-55.

Kent, N. L. (1983).Technology of Cereals. 3rd ed. New York: Pergamon Press.

Kinsella, J. E. (1976). Functional properties of protein in food-A survey. Crit Rev Food Sci Nutr, 5, 219-225. https://doi.org/10.1080/10408397609527208

Kirssel, L. and Prentice, M. (1979). Protein and fiber enrichment of cookie flour with brewer's spent grain. Cereal Chem, 50(4), 261-265.

Kulkarni, K. D., Kulkarni, D. N. and Ingle, U. M. (1991). Sorghum malt-based weaning formulations: preparation, functional properties and nutritive value Food and Nutrition Bulletin, $13 \quad$ (4), $322-\quad 327$ https://doi.org/10.1177/156482659101300401 
Lakshmi, M., Swarnali, D. M., \& Usha, R. (2015). Development and analysis of composite flour bread. J Food Sci Technol, 52(7), 4156-4165. https://doi.org/10.1007/s13197-014-1466-8

Larrauri, J. A., Ruperez, P., Borroto, B. \& Saura-Calixto, F. (1996). Mango peels as a new tropical fiber: Preparation and characterization. Lebensmittel$\begin{array}{lll}\text { Wissenschaftund } & \text { Technologie, } & \text { 29(8), }\end{array}$ https://doi.org/10.1006/fstl.1996.0113

Laura, C. O. \& Eric, C. O. (2014). Development of cookies made with cocoyam, fermented sorghum and germinated pigeon pea flour blends using response surface methodology. Journal of Food Science Technology, 51(10), 2671-2677. https://doi.org/10.1007/s13197-012-0749-1

Laura, O., Eric, O. \& Emelem, U. (2013). Physico-chemical and sensory properties of cookies made from blends of germinated pigeon pea, fermented sorghum, and cocoyam flours. Food Science \& Nutrition, 1(1), 8-14 https://doi.org/10.1002/fsn3.2

Manley, D. 2000. Technology of biscuits, crackers and cookies. $2^{\text {nd }}$ ed. p. 85 London: Ellis Horwood Limited.

Michel, C. A. P., Maria, F. P. B., Rafaela, C. P., Juciane, A. R. P., Raimundo, V. S. (2016). Chemical composition of unripe banana peels and pulps flours and its effects on blood glucose of rats. Nutrition \& Food Science, 46(4), 504-516. https://doi.org/10.1108/nfs-11-2015-0150

Nassar, A. G., AbdEl-Hamied, A. A. and El-Naggar, E. A. (2008). Effect of citrus by-products flour incorporation on chemical, rheological and organoleptic characteristics of biscuits. World Journal of Agricultural Sciences, 4 (5), 612616.

Noor Aziah, A. A. and Komathi, C. A. (2009). Acceptability attributes of crackers made from different types of composite flour. International Food Research Journal, 16, 479-482.

Ogbonna, O. A., Izundu, A. I., Ikeyi, A. P. \& Ohia, G. U. (2016). Proximate Compositions of fruits of Three Musa Species at Three Stages of Development. IOSR Journal of Dental and Medical Sciences (IOSR-JDMS), 15( 6), 107-117. https://doi.10.9790/0853-150611107117

Ojinnaka, M. C., Akobundu, E. N. T. and Iwe, M. O. (2009). Cocoyam starch modification effects on functional, sensory and cookies qualities. Pakistan Journal of Nutrition, 8(5), 558-567. https://doi.org/10.3923/pjn.2009.558.567

Okafor, J. N., Ozumba, A. U., \& Solomon, H. M. (2002). Production and acceptability of chinchin fortified with oyster mushroom. Nigeria Food Journal, $18,19-20$.

Okaka, J. C., Potter, N. N. (1977). Functional and storage properties of cow peawheat flour blends in bread making. $J$ Food Sci, 42(3), 828-833. https://doi.org/10.1111/j.1365-2621.1977.tb12614.x

Okpala, L. C. and E. C. Okoli. (2011). Nutritional evaluation of cookies produced from blends of pigeon peas, cocoyam and sorghum flour blends. Afr. J. Biotechnol, 10(3), 433-438.

Oyeku, O. M., Kupoluyi, C. F., Osibanjo, A. A., Orji, C. U., Ajuebor, F. N., Ajiboshin, I. O. and Asiru W. B. (2008). An economic assessment of commercial production of $10 \%$ cassava. J Ind Res Technol, 2(1), 13-20.

Raihan, M. and Saini, C. S. (2017). Evaluation of various properties of composite flour from oats, sorghum, amaranth and wheat flour and production of cookies thereof. International Food Research Journal, 24(6), 2278-2284. http://agris.upm.edu.my:8080/dspace/handle/0/16067

Rodriguez-Ambriz, S. L., Islas-Hernández, J. J., Agama-Acevedo, E., Tovar J., \& Bello-Pérez, L. A. (2008). Characterization of a fiber-rich powder prepared by liquefaction of unripe banana flour. Food Chemistry, 107(4), 1515-1521. https://doi.org/10.1016/j.foodchem.2007.10.007

Romelle, F. D., Ashwini, R. P. \& Ragu, S. M. (2016). Chemical composition of some selected fruit peels. European Journal of Food Science and Technology, $4(4), 12-21$.

Rungsinee, S. \& Natcharee, P. (2007). Oxygen permeability and mechanical properties of banana films. Food Research International, 40(3), 365-370. https://doi.org/10.1016/j.foodres.2006.10.010

Semwat, A. D., Narsimhamurty, M. C. \& Arya, S. S. (1996). Composition of some commercially available biscuits. J Food Sci Tech, 33,112-115.

Singh, S., Riar, C. S. and Saxena D. C. (2008). Effect of incorporating sweet potato flour to wheat flour on the quality characteristics of cookies. African Journal of Food Science, 2, 65-72. https://doi.org/10.13140/RG.2.2.28963.30249 Steele, R. G. D., \& Torrie, J. H. (1980). Principles and Procedures of Statistics McGraw-Hill Book Company Inc. New York, USA.

Yasumatsu, K., Sawada, K., Maritaka, S., Toda, J., Wada, T., Ishi, K. (1972) Whipping and emulsifying properties of soy bean products. Agri Biol Chem, 36(5), 719-727. https://doi.org/10.1080/00021369.1972.10860321 